\title{
New Molecular Tool for a Quick and Easy Detection of Apple Scab in the Field
}

\author{
Sara Franco Ortega ${ }^{1}$, Simona Prencipe ${ }^{2}$ (D), Maria Lodovica Gullino ${ }^{1,2}$ and Davide Spadaro ${ }^{1,2, *(\mathbb{D})}$ \\ 1 Centre of Competence for the Innovation in the Agro-environmental Sector-AGROINNOVA, University of \\ Turin, via Paolo Braccini 2, I-10095 Grugliasco, Italy; sarafrancoortega@gmail.com (S.F.O.); \\ marialodovica.gullino@unito.it (M.L.G.) \\ 2 Department of Agricultural, Forestry and Food Sciences (DiSAFA), University of Torino, via Paolo Braccini 2, \\ I-10095 Grugliasco, Italy; simona.prencipe@unito.it \\ * Correspondence: davide.spadaro@unito.it
}

Received: 30 March 2020; Accepted: 15 April 2020; Published: 18 April 2020

check for updates

\begin{abstract}
Venturia inaequalis, an agent of apple scab, is the most important pathogen of Malus $\mathrm{x}$ domestica. Control measures against this pathogen rely on intensive phytosanitary programs based on predictive models to identify the meteorological conditions conducive to the primary infection. The detection of the pathogen in field, both in naturally infected symptomatic and asymptomatic leaves, is desirable. Loop-mediated isothermal amplification (LAMP) assays are profitable molecular diagnostic tools for the direct detection of pathogens in field. A LAMP assay for V. inaequalis has been designed on the elongation factor 1-alpha sequence. The validation of the LAMP assay was carried out following the international EPPO standard PM 7/98 in terms of specificity, sensitivity, repeatability and reproducibility. Specificity testing was performed using target and non-target species, such as phylogenetically related Venturia species and other pathogens commonly found in apple, resulting in positive amplification only for the target with a time to positive ranging from 20 to $30 \mathrm{~min}$. Sensitivity testing was performed with serial dilutions of DNA of the target and by artificial inoculation of young apple leaves. The reliability of the LAMP assay as an early-detection tool and its user-friendly application make it suitable for the diagnosis of apple scab in the field.
\end{abstract}

Keywords: apple scab; diagnosis; on-site; LAMP

\section{Introduction}

Venturia inaequalis Cook (Wint.) is the causal agent of apple scab disease, the most important disease on apple orchards in temperate countries with cool and wet weather during early spring [1]. It is a worldwide-distributed species affecting all the apple growing countries and causing important economic and yield losses [1-5].

Most commercial apple varieties are susceptible to $V$. inaequalis [6,7], and the use of resistant apple varieties is highly recommended, though unfortunately, some scab-resistant cultivars are not appreciated by the consumers [8]. Consequently, management strategies such as chemical, physical and biological control as well as sanitation practices, leaf shredding and reduction of leaf litter, are applied to suppress the sexual stage during autumn [1,9-12]. Several treatments with fungicides are applied during the cropping season to reduce the ascospore infection, leading, throughout the last decades, to the development of $V$. inaequalis populations resistant to benzimidazoles, demethylation inhibitors, quinone outside inhibitors and dodine [13]. Alternative products have been applied to control resistant populations in orchards [14-16].

Considering the $V$. inaequalis life cycle, the primary infection is caused by the release of sexual spores from the asci produced in overwintering pseudothecia at or after bud break $[1,17,18]$. The 
primary infection period usually lasts 6 to 10 weeks, with an acute phase where the release of ascospores is elevated [19]. This time interval, which occurs contemporarily with the expansion of cluster leaves, is significant for fungicide application. Afterwards, secondary infections are caused by the conidia released during fruit development and by their dissemination through wind and rainfalls [20]. As a result, during summer, fungicide applications become infrequent or can even stop depending on the weather conditions.

In addition, due to the positive correlation between primary infections and abundant rainfall periods during spring, apple scab management programmes rely on predictive models based on weather alerts that permit the most suitable crop protection strategies to be implemented, which also depends on the susceptibility of apple variety and on the amount and frequency of rainfall [21-25].

Another key tool for monitoring V. inaequalis is spore trap devices [26-29]. Ascospores are captured on tapes in the field and then identified and quantified using microscope observation [25]. However, this method is laborious and time-consuming, and easier and faster methods for identification and monitoring of the pathogen are needed. Molecular methods overcome microscope observation in terms of sensitivity and specificity, as well as for speed of the analysis, and they have been widely used to monitor the presence of ascospores [28-30]. PCR-based methods for some species of Venturia have been designed on the sequence of internal transcribed spacer (ITS) or on the cytochrome 51A1 (CYP51A1) [31,32], while qPCR assays have been designed on a broader range of molecular regions including the ITS rDNA, ATP-binding cassette transporter 2 (ABC2), CYP51A1 and EF-1 $\alpha$ genes $[28-30,33]$. qPCR techniques have been used in combination with spore trap sampling, although their application requires a centralised laboratory, and the interpretation of the results is laborious. New molecular techniques for on-site detection can speed up the decision-making process, allowing the most suitable crop protection practices to be selected.

Loop-mediated isothermal amplification (LAMP) assay is a technique designed by Notomi et al. [34] and optimized by Nagamine et al. [35]. The LAMP assay consists of the amplification of a target DNA region in a specific, sensitive and fast way performed in isothermal conditions by means of six primers which recognize eight different regions on the target DNA and of an enzyme with high strand-displacement activity. One of the advantages of the LAMP is the resistance to common inhibitors found in the matrix that allow the use of quick extraction DNA methods based on the mechanical cell break [36]. This technique has been tested and validated for a wide range of plant pathogens, including phytoplasma, bacteria, virus and fungi [37-40]. It has been demonstrated as a suitable tool for in-field detection of pathogens using battery-powered platforms such at Genie III (Optigene, Horsham, UK) based on fluorescence detection of the LAMP products [38]. However, the LAMP products can also be visualized by means of turbidimetric or colorimetric techniques and using gel electrophoresis [41-43].

The aim of this study was to develop and validate, according to the international standard EPPO (PM7/98), a LAMP assay able to detect $V$. inaequalis in vitro and on apple leaves that can be used as a surveillance and monitoring tool to support decisions in crop protection against apple scab.

\section{Materials and Methods}

\subsection{Fungal Isolates and DNA Extraction}

The fungal isolates used in this study were obtained from apple scab monitoring studies performed in Piedmont (Northern Italy) during 2015 and 2016 of apple leaves (Table 1). The isolates, belonging to the Agroinnova collection (University of Turin, Italy), were previously identified by sequencing of the internal transcribed spacer (ITS) region using the primers ITS1/ITS4 and elongation factor-1-alpha with EF1/EF2 [44,45]. 
Table 1. Inclusion-exclusion panel to check the specificity of the loop-mediated isothermal amplification (LAMP) assay using DNA of $V$. inaequalis, phylogenetically related species and other common pathogens present in apple orchards.

\begin{tabular}{|c|c|c|c|c|}
\hline \multirow{2}{*}{ Species } & \multirow{2}{*}{ Isolate Name } & \multirow{2}{*}{ Host } & \multicolumn{2}{|c|}{ Lamp Assay } \\
\hline & & & Tp (min:s) & Anneal $\left({ }^{\circ} \mathrm{C}\right)$ \\
\hline Venturia inaequalis & $2.16 \mathrm{~B} 9$ & Malus $\mathrm{x}$ domestica var. Ambrosia & $29: 28 \pm 01: 40$ & $89.72 \pm 0.13$ \\
\hline V. inaequalis & $2.16 \mathrm{~B} 1$ & Malus x domestica var. Ambrosia & $26: 67 \pm 01: 30$ & $89.38 \pm 0.03$ \\
\hline V. inaequalis & $2.16 \mathrm{~B} 6$ & Malus $\mathrm{x}$ domestica var. Ambrosia & $24: 04 \pm 00: 49$ & $89.08 \pm 0.03$ \\
\hline V. inaequalis & 2.16 B7 & Malus $\mathrm{x}$ domestica var. Ambrosia & $26: 37 \pm 00: 52$ & $89.06 \pm 0.15$ \\
\hline V. inaequalis & $2.16 \mathrm{~B} 5$ & Malus x domestica var. Ambrosia & $23: 48 \pm 00: 58$ & $89.36 \pm 0.39$ \\
\hline V. inaequalis & $2.16 \mathrm{~B} 10$ & Malus x domestica var. Ambrosia & $24: 43 \pm 00: 46$ & $89.36 \pm 0.39$ \\
\hline V. inaequalis & $4.16 \mathrm{~A} 4$ & Malus x domestica var. Golden Delicious & $25: 18 \pm 04: 14$ & $89.36 \pm 0.15$ \\
\hline V. inaequalis & $4.16 \mathrm{~A} 6$ & Malus x domestica var. Golden Delicious & $27: 18 \pm 05: 56$ & $89.60 \pm 0.08$ \\
\hline V. inaequalis & $4.16 \mathrm{~A} 7$ & Malus x domestica var. Golden Delicious & $24: 18 \pm 00: 35$ & $89.49 \pm 0.16$ \\
\hline V. inaequalis & 4.16 A9 & Malus x domestica var. Golden Delicious & $29: 59 \pm 09: 14$ & $89.12 \pm 0.41$ \\
\hline V. inaequalis & $4.16 \mathrm{~A} 10$ & Malus x domestica var. Golden Delicious & $22: 50 \pm 01: 50$ & $89.19 \pm 0.03$ \\
\hline V. inaequalis & $3.16 \mathrm{~B} 1$ & Malus x domestica var. Ambrosia & $29: 53 \pm 02: 51$ & $89.64 \pm 0.33$ \\
\hline V. inaequalis & $3.16 \mathrm{~B} 2$ & Malus x domestica var. Ambrosia & $30: 05 \pm 04: 07$ & $89.11 \pm 0.35$ \\
\hline$V$. inaequalis & $3.16 \mathrm{~B} 6$ & Malus x domestica var. Ambrosia & $27: 43 \pm 05: 28$ & $89.76 \pm 0.07$ \\
\hline$V$. inaequalis & $3.16 \mathrm{~B} 7$ & Malus x domestica var. Ambrosia & $27: 03 \pm 01: 37$ & $89.65 \pm 0.43$ \\
\hline V. inaequalis & $3.16 \mathrm{~B} 7$ & Malus x domestica var. Ambrosia & $28: 14 \pm 04: 52$ & $89.69 \pm 0.23$ \\
\hline V. inaequalis & 3.16 B9 & Malus $\mathrm{x}$ domestica var. Ambrosia & $28: 30 \pm 03: 23$ & $89.49 \pm 0.33$ \\
\hline V. inaequalis & 5.161 & Malus x domestica var. Ambrosia & $30: 13 \pm 00: 49$ & $89.34 \pm 0.15$ \\
\hline$V$. inaequalis & 5.162 & Malus $\mathrm{x}$ domestica var. Ambrosia & $28: 09 \pm 00: 26$ & $89.65 \pm 0.01$ \\
\hline$V$. inaequalis & 5.163 & Malus x domestica var. Ambrosia & $31: 55 \pm 05: 43$ & $89.26 \pm 0.53$ \\
\hline V. inaequalis & 5.164 & Malus $\mathrm{x}$ domestica var. Ambrosia & $26: 46 \pm 03: 52$ & $89.60 \pm 0.07$ \\
\hline V. inaequalis & 5.165 & Malus $\mathrm{x}$ domestica var. Ambrosia & $23: 20 \pm 01: 36$ & $89.07 \pm 0.02$ \\
\hline V. inaequalis & 5.166 & Malus x domestica var. Ambrosia & $26: 12 \pm 01: 05$ & $89.64 \pm 0.40$ \\
\hline$V$. inaequalis & 1BG8 & Malus x domestica var. Ambrosia & $27: 37 \pm 00: 31$ & $89.34 \pm 0.01$ \\
\hline V. inaequalis & $1 \mathrm{~B} 9$ & Malus x domestica var. Ambrosia & $26: 20 \pm 02: 41$ & $89.75 \pm 0.18$ \\
\hline$V$. inaequalis & 1B1 & Malus $\mathrm{x}$ domestica var. Ambrosia & $23: 36 \pm 00: 08$ & $89.75 \pm 0.18$ \\
\hline V. inaequalis & $1 \mathrm{~B} 2$ & Malus x domestica var. Ambrosia & $22: 06 \pm 00: 45$ & $89.44 \pm 0.43$ \\
\hline V. inaequalis & $1 \mathrm{~B} 3$ & Malus x domestica var. Ambrosia & $27: 35 \pm 04: 40$ & $89.73 \pm 0.56$ \\
\hline V. inaequalis & $1 \mathrm{~B} 5$ & Malus x domestica var. Ambrosia & $22: 37 \pm 00: 32$ & $89.43 \pm 0.25$ \\
\hline V. inaequalis & $3 \mathrm{~A} 1$ & Malus x domestica var. Mondial Gala & $20: 47 \pm 00: 59$ & $89.64 \pm 0.25$ \\
\hline V. inaequalis & 3AC & Malus x domestica var. Mondial Gala & $23: 05 \pm 00: 22$ & $89.80 \pm 0.01$ \\
\hline V. inaequalis & 3AF & Malus x domestica var. Mondial Gala & $22: 47 \pm 00: 37$ & $89.71 \pm 0.10$ \\
\hline V. inaequalis & $3 \mathrm{AH}$ & Malus x domestica var. Mondial Gala & $23: 39 \pm 01: 08$ & $89.81 \pm 0.01$ \\
\hline V. asperata & IRHS 2345 & Malus x domestica & Negative & Negative \\
\hline V. carpophila & CBS 497.62 & Prunus mirabelle $\mathrm{n}$ & Negative & Negative \\
\hline V. pirina & CBS120.825 & Pyrus communis & Negative & Negative \\
\hline V. nashicola & CBS 793.84 & Pyrus serotina var Culta & Negative & Negative \\
\hline Alternaria alternata & CBS 115152 & Psychotria serpens & Negative & Negative \\
\hline Alternaria alternata & CBS 116329 & Malus $\mathrm{x}$ domestica & Negative & Negative \\
\hline Alternaria alternata & ATCC 34509 & Malus $\mathrm{x}$ domestica & Negative & Negative \\
\hline Alternaria mali & CBS 106.24 & Malus sylvestris & Negative & Negative \\
\hline Botrytis cinerea & $\mathrm{BC} 1$ & Unknown & Negative & Negative \\
\hline Botrytis cinerea & $\mathrm{BC} 2$ & Unknown & Negative & Negative \\
\hline Botryospheria berengerina & 1544 & Unknown & Negative & Negative \\
\hline Botryosphaeria laricina & 1547 & Unknown & Negative & Negative \\
\hline Cladosporium sp. & 405 & Unknown & Negative & Negative \\
\hline Colletotrichum acutatum & 256 & Unknown & Negative & Negative \\
\hline Colletotrichum acutatum & 2692 & Unknown & Negative & Negative \\
\hline Colletotrichum kahawae & colletoSalv & Unknown & Negative & Negative \\
\hline Colletotrichum truncatum & 1540 & Unknown & Negative & Negative \\
\hline Colletotrichum sp. & Coll_IT & Unknown & Negative & Negative \\
\hline Cylindrocarpon & 452 & Unknown & Negative & Negative \\
\hline Epicoccum sp. & epic_IT & Unknown & Negative & Negative \\
\hline Eutypa lata & 308 & Unknown & Negative & Negative \\
\hline Fusarium sp. & Fussp & Unknown & Negative & Negative \\
\hline Fusarium equiseti & FEQ_L8 & Unknown & Negative & Negative \\
\hline Fusarium equiseti & FEQ_1.14 & Unknown & Negative & Negative \\
\hline Fusarium oxysporum & Mya3040 & Unknown & Negative & Negative \\
\hline Monilinia laxa & 1402 & Unknown & Negative & Negative \\
\hline Monilinia fructicola & 1326 & Unknown & Negative & Negative \\
\hline Monilina polystroma & M. polys_1 & Unknown & Negative & Negative \\
\hline Phoma sp. & t152 & Unknown & Negative & Negative \\
\hline Phoma sp. & t109 & Unknown & Negative & Negative \\
\hline Phoma sp. & Phoma1 & Unknown & Negative & Negative \\
\hline Phoma betae & Pbet1 & Unknown & Negative & Negative \\
\hline Phoma trachiephilium & Ptrach1 & Unknown & Negative & Negative \\
\hline Phoma bellidis & Pbellid1 & Unknown & Negative & Negative \\
\hline Stemphylium bellidis & IT50 & Unknown & Negative & Negative \\
\hline Trichoderma sp. & 268 & Unknown & Negative & Negative \\
\hline Verticillium dahlie & VD1 & Unknown & Negative & Negative \\
\hline
\end{tabular}


The DNA from single-spore culture of the fungal isolates growing for one month on potato dextrose agar (PDA) at $22{ }^{\circ} \mathrm{C}$, was extracted and stored in sterile tubes at $4{ }^{\circ} \mathrm{C}$. The mycelium was obtained by scratching the mycelium from the growing region on a Petri dish. The total genomic DNA was obtained using an E.Z.N.A Fungal DNA mini kit (OMEGA Bio-Tek, Norcross, GA, USA), according to the manufacturer's instructions. The DNA concentration of each isolate was measured using Nanodrop 2000 (ThermoFisher, Monza, Italy). The final concentration used for LAMP assay validation was adjusted to $1-50 \mathrm{ng} / \mu \mathrm{L}$.

Alkaline DNA extraction was used to extract the DNA from plugs of the artificially inoculated apple leaves ( $1.5 \mathrm{~cm}$ diameter plugs) and from naturally infected symptomatic and asymptomatic apple leaves (1.5 cm diameter plugs), to perform a crude extraction method, as described by Franco Ortega et al. [46,47]. The extraction included one 7/16" stainless steel 316 GD ball (Spheric Trafalgar Ltd., Worthing, UK) and $1 \mathrm{~mL}$ of $\mathrm{pH}$ 13-13.5 PEG buffer (50 g/L PEG average Mn 4600; $20 \mathrm{mmol} / \mathrm{L}$ $\mathrm{KOH} ; \mathrm{pH} 13.5)$ in a $5 \mathrm{~mL}$ tube homogenized by vigorous manual shaking for one minute. At the same time, other plugs of the same diameter and from the same artificially inoculated and naturally infected leaves were extracted using an E.Z.N.A. Fungal DNA kit (OMEGA Bio-Tek), according to manufacturer's instructions, with a preceding cell rupture using liquid nitrogen. Both DNAs were used as targets for the LAMP assay to compare the reliability of the crude extraction method.

\subsection{Loop-Mediated Isothermal Amplification (LAMP) Primer Design and LAMP Reaction}

LAMP primers, including two external primers (F3 and B3), two internal primers (FIP and BIP) and a loop primer (F-loop), were designed on the EF- $1 \alpha$ sequence taking into account the procedure reported by Notomi et al. [39] and Nagamine et al. [40]. Sequences of EF-1 $\alpha$ gene were aligned from phylogenetically closely related Venturia spp. obtained from the NCBI GenBank (Table S1) to check the specificity of the primers. OligoCalc program [48] and Multiple Primer Analyzer programs (https://www.thermofisher.com/uk/en/home/brands/thermo-scientific/molecular-biology/molecularbiology-learning-center/molecular-biology-resource-library/thermo-scientific-web-tools/multipleprimer-analyzer.html) were used to check any possible secondary structures, hairpins, self-annealing and primer dimers. The specificity of the sequence of the six LAMP primers as well as the LAMP target sequence was checked using BLASTn analysis. The primers were synthesized and HPLC purified using Eurofins (UK).

The LAMP reactions for the detection of $V$. inaequalis were carried out using $1 \mu \mathrm{L}$ of DNA $(1-50 \mathrm{ng} / \mu \mathrm{L})$ of the isolates listed in Table 1 or with $1 \mu \mathrm{L}$ of the 1:10 diluted DNA from crude extraction. Cytochrome oxidase gene (COX) LAMP assay was used as internal control of the leaf DNA extraction with $1 \mu \mathrm{L}$ of the 1:10 diluted DNA from crude extraction [36]. The LAMP reactions for $V$. inaequalis and for COX were prepared on $25 \mu \mathrm{L}$ reaction including $0.2 \mu \mathrm{mol} / \mathrm{L}$ of the external primers (F3 and B3), $2 \mu \mathrm{mol} / \mathrm{L}$ of each internal primer (FIP and BIP), $1 \mu \mathrm{mol} / \mathrm{L}$ of each loop primer and $1 \times$ Isothermal Mastermix ISO-004 ${ }^{\circledR}$ (OptiGene Ltd.,Horsham, UK). LAMP assay was performed as reported by Franco Ortega et al. [47] with both a Genie $\mathrm{II}^{\circledR}$ instrument and a StepOne instrument (Applied Biosystem, Loughborough, UK) set to perform an amplification at $65^{\circ} \mathrm{C}$ for $45 \mathrm{~min}$ and measurement of annealing temperature.

\subsection{Real-Time $q P C R$}

A qPCR using a TaqMan assay designed by Prencipe et al. [33] was used to calculate the inoculum concentration and to validate the LAMP assay on naturally infected leaves as well as artificially inoculated leaves. qPCR reaction was performed in $20 \mu \mathrm{L}$ using $1 \mu \mathrm{L}$ of each extracted DNA, $0.3 \mu \mathrm{M}$ of each primer (Forward-5'-CACTTCCCCGCTATTCACGT- $3^{\prime}$ and Reverse-5'-GCAATCGTTAGCATCGTCATAGTG-3'), $0.1 \mu \mathrm{M}$ of the TaqMan probe (5'-FAM-CTCAAGGCAGCCCAACTTTCTCCGGT-BHQ1-3') and $1 \times$ of Universal TaqMan MasterMix (Applied Biosystems) on a StepOne instrument (Applied Biosystems) conducted with an initial step at $50{ }^{\circ} \mathrm{C}$ for $2 \mathrm{~min}, 95^{\circ} \mathrm{C}$ for $10 \mathrm{~min}, 40$ cycles of $15 \mathrm{~s}$ at $95^{\circ} \mathrm{C}$ and $15 \mathrm{~s}$ at $60^{\circ} \mathrm{C}$. All samples were amplified 
in triplicate. A 10-fold serial diluted standard curve with the DNA of the $1 \mathrm{~B} 3$ isolate ( $20 \mathrm{ng}$ to $20 \mathrm{fg}$ ) and a negative control with water instead of DNA was included in each reaction. In order to estimate the number of $V$. inaequalis cells in each sample, the Ct obtained with the qPCR assay was compared against a standard curve to obtain the ng of DNA present in $1 \mu \mathrm{L}$. Later this number was divided by the $V$. inaequalis genome weight $(0.0000597 \mathrm{ng}$ of the reference strain ICMP13258) [49]. This number represents the cells detected using the LAMP using commercial DNA extraction. On the other hand, the elution volume of the commercial DNA extraction $(20 \mu \mathrm{L})$ was taken into consideration in order to obtain an approximate number of cells present on the inoculated leaves extracted with the crude method. Due to the nature of the crude extraction of DNA, the solution was posteriorly 1:10-diluted to reduce possible chlorophyll fluorescence interference, before performing the LAMP.

\subsection{Sensitivity Testing}

'Golden Delicious' apple leaves were used to evaluate the detection limit in terms of the lowest number of cells detected using the LAMP assay. Young leaves (3-days old) were previously treated with sodium hypochlorite $(2 \%)$ for $30 \mathrm{~s}$, rinsed with distilled water and then air-dried for $30 \mathrm{~min}$ before making $1.5 \mathrm{~cm}$-diameter plugs. Six plugs were obtained from each leaf, two as negative controls, in which no inoculum was added, and four for the artificial inoculation of $V$. inaequalis. V. inaequalis inoculum was prepared from isolate $1 \mathrm{~B} 3$ of $V$. inaequalis grown on PDA at $22{ }^{\circ} \mathrm{C}$ for 1 month. The mycelium was scratched from the Petri dishes and resuspended in potato dextrose broth to maintain the viability of the cells. Four different volumes $(10 \mu \mathrm{L}, 20 \mu \mathrm{L}, 30 \mu \mathrm{L}$ and $40 \mu \mathrm{L})$ from the inoculum suspension were placed on the leaf plugs. Thirty min after inoculation, the plugs were used to perform a crude extraction (two plugs) and a commercial DNA extraction (two plugs). The LAMP assay was performed using DNA from both extractions and to help understand the sensitivity of the LAMP assays using a crude extraction; other biological replicates were extracted with a commercial kit, and the number of cells inoculated were calculated using a qPCR assay with the formula described above.

\subsection{Monitoring Over Time of V. inaequalis Infected Leaves}

To monitor the reliability of the LAMP assay over time, a 9-day experiment that included 6 sampling time points was performed. Young 'Golden Delicious' apple leaves were prepared as explained above. Six 1.5-cm diameter plugs were obtained from each leaf and were inoculated with $30 \mu \mathrm{L}$ of the $V$. inaequalis suspension. Three plugs were used for each type of DNA extraction (crude extraction and commercial kit extraction). Three-sector Petri dishes (VWR, Milan, Italy) were used to store three plugs placed on a cell chamber at $22{ }^{\circ} \mathrm{C}$ with $75 \%$ humidity. Each plug was used to perform three technical replicates of the LAMP assay. The number of cells inoculated was calculated after DNA extraction, using the qPCR assay with a TaqMan probe as described above. The assay was performed twice.

\subsection{Validation of the LAMP Assays}

$V$. inaequalis LAMP assay was validated according to the international standard EPPO PM7/98 in terms of the specificity, sensitivity, repeatability, and reproducibility. The specificity test was carried out using a panel of inclusion/exclusion composed by the target DNA of $32 \mathrm{~V}$. inaequalis isolates from 'Ambrosia', 'Golden Delicious' and 'Gala' apple leaves, and by phylogenetically closely related Venturia species, such as $V$. pirnia, $V$. nashicola, $V$. carpophila and $V$. asperata as well as by other fungi commonly found in apple orchards. The sensitivity was evaluated on in vitro and in vivo samples. Ten-fold serial dilutions of three isolates of $V$. inaequalis (1B10 and 1B7 from Malus x domestica 'Ambrosia', 3AF from Malus $\mathrm{x}$ domestica 'Golden Delicious') were used to evaluate the sensitivity of the LAMP assay with DNA, whilst artificially inoculated apple leaves at different concentrations were used to evaluate the sensitivity using real samples. All the LAMP reactions were performed three times to evaluate the repeatability (using DNA, artificially inoculated samples and naturally infected samples), while the reproducibility was evaluated by running the assays on different machines, on different days and by 
two members of the laboratory. Reliability of the crude extraction results was assessed against the results of the LAMP assay using a commercial DNA extraction kit.

\subsection{Analytical Specificity and Sensitivity Assays}

A comparison between the crude extraction results and the commercial kit leaf extraction, using real samples, was performed in order to evaluate the diagnostic sensitivity (DSe) or true-positive rate and analytical specificity (DSp) of the true-negative rate. Both ratios were calculated using the following formula: Specificity $=\Sigma \mathrm{TP} /(\Sigma \mathrm{TP}+\mathrm{FN})$; Sensitivity $=\Sigma \mathrm{TN} /(\Sigma \mathrm{TN}+\mathrm{FP})$; where TP (true positive) is the really positive samples in the experiment, TN (true negative) is the really negative samples, FN (false negative) is the leave samples that gave a LAMP negative result after the crude extraction and a positive result after the commercial DNA extraction and the FP (false positive) is the number of samples that produced a positive result after using a crude extraction but were not artificially inoculated [34]. After these calculations, the likelihood positive ratio (LR+) and the likelihood negative ratio (LR-) were calculated, respectively, as the ratio between the specificity and the FP-rate, and the FP-rate and sensitivity, using the calculator tool Diagnostic Test Calculator program (http://araw.mede.uic.edu/cgi-bin/testcalc.pl).

\section{Results}

\subsection{Validation of the LAMP Assay}

The results of the BLASTn of the LAMP primers, (F3: CGA GAA GGT AAG GCA TTT ATT CA; FIP: TTC GAA ATG AAA TCC GGG TTG GGC TG CTT TGT TAT CAC CCT CAC TGC, loopF: CCA CAG TGC AAA ATT TGC GTT GCC, BIP: AGT GTC CCG CAC TTC CCC GCT ATT C TTG GGC TGC CTT GAG TGG C, B3: CGT CAK ART GAA AGA TGG GAC C) showed 100\% identity with $V$. inaequalis CBS 815.69, CBS 330.65, CBS 595.70 and CBS 121.310 (GenBank accession numbers KJ747043, KJ747042, KJ747041, KJ747040). No hairpin, secondary structures or self-annealing were shown within the LAMP primers.

The inclusion-exclusion panel (Table 1) showed that no amplification was obtained with phylogenetically closed species, such as $V$. nashicola, V. pirina, V. carpophila and V. asperata, nor with other pathogens commonly found in apple orchards. Tp (time to positive) ranged from $20 \mathrm{~min}$ $47 \mathrm{~s}$ to $31 \mathrm{~min} 55 \mathrm{~s}$, whilst the annealing temperature ranged from $89.07^{\circ} \mathrm{C}$ to $89.81^{\circ} \mathrm{C}$. On the other hand, the sensitivity using the DNA of $3 \mathrm{~V}$. inaequalis strains (1B10, 3AF and 1B7) showed that the limit of detection was 9.9 to $1 \mathrm{pg}$ of DNA (Table 2).

The sensitivity of the LAMP assay was also evaluated using artificially inoculated 'Golden Delicious' leaves whose DNA was extracted using both types of extraction and compared with the number of cells calculated with the qPCR assay (Table 3). In the $10 \mu \mathrm{L}$ mycelia suspension-inoculation, only one out of twelve samples (approximately $4.7 \times 10^{4}$ cells in $1 \mathrm{~mL}$ of PEG buffer) produced a positive amplification with the DNA from crude extraction. The same samples tested with the DNA extracted with the commercial kit gave 5 out of 9 positive results in the first leaf tested and 4 out of 9 positive in the second leaf (from approximate $1.1 \times 10^{3}$ to $1.9 \times 10^{3}$ cells $/ \mu \mathrm{L}$ and from $7.5 \times 10^{2}$ to $1.9 \times 10^{3}$ cells $/ \mu \mathrm{L}$, respectively), with Tp ranging from $34 \mathrm{~min} 00 \mathrm{~s}$ to $39 \mathrm{~min} 22 \mathrm{~s}$ and annealing temperature ranging from 88.70 to $88.92^{\circ} \mathrm{C}$. 
Table 2. Sensitivity test using DNA of three V. inaequalis isolates.

\begin{tabular}{|c|c|c|c|c|c|c|c|c|c|}
\hline \multirow{2}{*}{ DNA Quantity } & \multicolumn{3}{|c|}{$\begin{array}{l}\text { Isolate 1B10 from Malus x domesticus var. } \\
\text { Ambrosia }\end{array}$} & \multicolumn{3}{|c|}{$\begin{array}{l}\text { Isolate 3AF from Malus x domesticus var. } \\
\text { Golden Delicious }\end{array}$} & \multicolumn{3}{|c|}{$\begin{array}{l}\text { Isolate 1B7 from Malus x domesticus var. } \\
\text { Ambrosia }\end{array}$} \\
\hline & TP (min:s) & Anneal $\left({ }^{\circ} \mathrm{C}\right)$ & $\begin{array}{l}\text { Number of } \\
\text { Positives }\end{array}$ & TP (min:s) & Anneal $\left({ }^{\circ} \mathrm{C}\right)$ & $\begin{array}{l}\text { Number of } \\
\text { Positives }\end{array}$ & TP (min:s) & Anneal $\left({ }^{\circ} \mathrm{C}\right)$ & $\begin{array}{l}\text { Number of } \\
\text { Positives }\end{array}$ \\
\hline $1-10 \mathrm{ng}$ & $35: 10 \pm 00: 42$ & $89.52 \pm 0.01$ & 3 & $31: 41 \pm 00: 24$ & $89.42 \pm 0.09$ & 3 & $29: 20 \pm 02: 53$ & $89.47 \pm 0.09$ & 3 \\
\hline $999 \mathrm{pg}-100 \mathrm{pg}$ & $38: 52 \pm 01: 53$ & $89.27 \pm 0.09$ & 3 & $34: 47 \pm 02: 48$ & $89.42 \pm 0.08$ & 3 & $35: 17 \pm 00: 43$ & $89.42 \pm 0.09$ & 3 \\
\hline $99 \mathrm{pg}-10 \mathrm{pg}$ & $42: 31 \pm 00: 47$ & $89.27 \pm 0.08$ & 3 & $38: 58 \pm 00: 54$ & $89.47 \pm 0.09$ & 3 & $43: 13 \pm 03: 28$ & $89.45 \pm 0.10$ & 2 \\
\hline $9.9 \mathrm{pg}-1 \mathrm{pg}$ & $41: 59 \pm 00: 00$ & 89.22 & 1 & $45: 50 \pm 00: 00$ & $89.22 \pm 0.00$ & 1 & $34: 03 \pm 00: 00$ & $89.37 \pm 0.00$ & 1 \\
\hline
\end{tabular}


Table 3. Sensitivity testing using different inoculum volumes and comparison between the LAMP assay performed with both types of DNA extractions (crude extraction and commercial extraction). Approximate number of cells in the crude DNA extraction and in the final elution of the commercial DNA extraction was calculated in other three biological replicates with the $\mathrm{qPCR}$ assay. Tp = time to positive, Anneal. = annealing temperature.

\begin{tabular}{|c|c|c|c|c|c|c|c|c|c|c|c|}
\hline & \multirow{2}{*}{ Samples } & & \multicolumn{3}{|c|}{ Crude DNA Extraction } & \multirow{2}{*}{$\begin{array}{c}\text { Approximate } \\
\text { Number of Cells } \\
\text { in } 1 \mathrm{~mL} \text { of PEG } \\
\text { Buffer }\end{array}$} & & \multicolumn{3}{|c|}{ Commmercial DNA Extraction } & \multirow{2}{*}{$\begin{array}{l}\text { Number of Cells in } 1 \mu \mathrm{L} \\
\text { of the Commercial DNA } \\
\text { Extraction }\end{array}$} \\
\hline & & & $\begin{array}{c}\text { Number of } \\
\text { Positives }\end{array}$ & TP (min:s) & Anneal. $\left({ }^{\circ} \mathrm{C}\right)$ & & & $\begin{array}{c}\text { Number of } \\
\text { Positives }\end{array}$ & TP (min:s) & Anneal. $\left({ }^{\circ} \mathrm{C}\right)$ & \\
\hline \multirow{6}{*}{$\begin{array}{c}10 \\
\mu \mathrm{L} \text {-mycelia } \\
\text { suspension }\end{array}$} & \multirow[b]{3}{*}{ LEAF 1} & PLUG 1 & $1 / 3$ & $40: 37$ & 88.92 & $4.8 \times 10^{4}$ & PLUG 3 & $2 / 3$ & $34: 00 \pm 02: 34$ & $88.70 \pm 0.10$ & $1.9 \times 10^{3}$ \\
\hline & & PLUG 2 & $0 / 3$ & Negative & Negative & $2.8 \times 10^{4}$ & PLUG 4 & $3 / 3$ & $39: 22 \pm 06: 53$ & $88.92 \pm 0.15$ & $1.1 \times 10^{3}$ \\
\hline & & $\begin{array}{l}\text { NEGATIVE } \\
\text { CONTROL }\end{array}$ & $0 / 3$ & Negative & Negative & 0 & $\begin{array}{l}\text { NEGATIVE } \\
\text { CONTROL }\end{array}$ & $0 / 3$ & Negative & Negative & 0 \\
\hline & \multirow{3}{*}{ LEAF 2} & PLUG 1 & $0 / 3$ & Negative & Negative & $3.9 \times 10^{4}$ & PLUG 3 & $2 / 3$ & $42: 18 \pm 10: 12$ & $88.55 \pm 0.10$ & $1.5 \times 10^{3}$ \\
\hline & & PLUG 2 & $0 / 3$ & Negative & Negative & $2.0 \times 10^{4}$ & PLUG 4 & $2 / 3$ & $41: 53 \pm 05: 03$ & $88.70 \pm 0.10$ & $7.9 \times 10^{2}$ \\
\hline & & $\begin{array}{l}\text { NEGATIVE } \\
\text { CONTROL }\end{array}$ & $0 / 3$ & Negative & Negative & 0 & $\begin{array}{l}\text { NEGATIVE } \\
\text { CONTROL }\end{array}$ & $0 / 3$ & Negative & Negative & 0 \\
\hline \multirow{6}{*}{$\begin{array}{c}20 \\
\mu \mathrm{L}-\mathrm{mycelia} \\
\text { suspension }\end{array}$} & \multirow{3}{*}{ LEAF 1} & PLUG 1 & $0 / 3$ & Negative & Negative & $4.3 \times 10^{4}$ & PLUG 3 & $2 / 3$ & $39: 49 \pm 07: 48$ & $88.85 \pm 0.10$ & $1.7 \times 10^{3}$ \\
\hline & & PLUG 2 & $0 / 3$ & Negative & Negative & $9.7 \times 10^{4}$ & PLUG 4 & $3 / 3$ & $44: 46 \pm 03: 47$ & $88.43 \pm 0.09$ & $3.8 \times 10^{3}$ \\
\hline & & $\begin{array}{l}\text { NEGATIVE } \\
\text { CONTROL }\end{array}$ & $0 / 3$ & Negative & Negative & 0 & $\begin{array}{l}\text { NEGATIVE } \\
\text { CONTROL }\end{array}$ & $0 / 3$ & Negative & Negative & 0 \\
\hline & \multirow{3}{*}{ LEAF 2} & PLUG 1 & $0 / 3$ & Negative & Negative & $1.2 \times 10^{4}$ & PLUG 3 & $0 / 3$ & Negative & Negative & $5.0 \times 10^{2}$ \\
\hline & & PLUG 2 & $0 / 3$ & Negative & Negative & $7.4 \times 10^{3}$ & PLUG 4 & $1 / 3$ & $36: 33$ & 88.92 & $2.9 \times 10^{2}$ \\
\hline & & $\begin{array}{l}\text { NEGATIVE } \\
\text { CONTROL }\end{array}$ & $0 / 3$ & Negative & Negative & 0 & $\begin{array}{l}\text { NEGATIVE } \\
\text { CONTROL }\end{array}$ & $0 / 3$ & Negative & Negative & 0 \\
\hline \multirow{6}{*}{$\begin{array}{c}30 \\
\mu \mathrm{L}-\text { mycelia } \\
\text { suspension }\end{array}$} & \multirow{3}{*}{ LEAF 1} & PLUG 1 & $1 / 3$ & $30: 14$ & 89.37 & $7.2 \times 10^{4}$ & PLUG 3 & $1 / 3$ & $35: 32$ & 87.73 & $2.9 \times 10^{3}$ \\
\hline & & PLUG 2 & $0 / 3$ & Negative & Negative & $9.5 \times 10^{4}$ & PLUG 4 & $1 / 3$ & 34:02 & 88.02 & $3.8 \times 10^{3}$ \\
\hline & & $\begin{array}{l}\text { NEGATIVE } \\
\text { CONTROL }\end{array}$ & $0 / 3$ & Negative & Negative & 0 & $\begin{array}{l}\text { NEGATIVE } \\
\text { CONTROL }\end{array}$ & $0 / 3$ & Negative & Negative & 0 \\
\hline & \multirow{3}{*}{ LEAF 2} & PLUG 1 & $0 / 3$ & Negative & Negative & $2.5 \times 10^{4}$ & PLUG 3 & $0 / 3$ & Negative & Negative & $1.0 \times 10^{3}$ \\
\hline & & PLUG 2 & $0 / 3$ & Negative & Negative & $3.0 \times 10^{4}$ & PLUG 4 & $0 / 3$ & Negative & Negative & $1.2 \times 10^{3}$ \\
\hline & & $\begin{array}{l}\text { NEGATIVE } \\
\text { CONTROL }\end{array}$ & $0 / 3$ & Negative & Negative & 0 & $\begin{array}{l}\text { NEGATIVE } \\
\text { CONTROL }\end{array}$ & $0 / 3$ & Negative & Negative & 0 \\
\hline \multirow{6}{*}{$\begin{array}{c}40 \\
\mu \mathrm{L}-\mathrm{mycelia} \\
\text { suspension }\end{array}$} & \multirow{3}{*}{ LEAF 1} & PLUG 1 & $1 / 3$ & 41:48 & 88.77 & $4.3 \times 10^{4}$ & PLUG 3 & $0 / 3$ & Negative & Negative & $1.7 \times 10^{3}$ \\
\hline & & PLUG 2 & $0 / 3$ & Negative & Negative & $9.0 \times 10^{4}$ & PLUG 4 & $1 / 3$ & 34:41 & 88.17 & $3.6 \times 10^{3}$ \\
\hline & & $\begin{array}{l}\text { NEGATIVE } \\
\text { CONTROL }\end{array}$ & $0 / 3$ & Negative & Negative & 0 & $\begin{array}{l}\text { NEGATIVE } \\
\text { CONTROL }\end{array}$ & $0 / 3$ & Negative & Negative & 0 \\
\hline & \multirow{3}{*}{ LEAF 2} & PLUG 1 & $0 / 3$ & Negative & Negative & $4.7 \times 10^{4}$ & PLUG 3 & $0 / 3$ & Negative & Negative & $1.9 \times 10^{3}$ \\
\hline & & PLUG 2 & $2 / 3$ & $39: 41 \pm 03: 29$ & $88.85 \pm 0.31$ & $8.4 \times 10^{4}$ & PLUG 4 & $0 / 3$ & Negative & Negative & $3.3 \times 10^{3}$ \\
\hline & & $\begin{array}{l}\text { NEGATIVE } \\
\text { CONTROL }\end{array}$ & $0 / 3$ & Negative & Negative & 0 & $\begin{array}{l}\text { NEGATIVE } \\
\text { CONTROL }\end{array}$ & $0 / 3$ & Negative & Negative & 0 \\
\hline
\end{tabular}


The $20 \mu \mathrm{L}$ mycelia suspension did not produce any positive amplification using DNA extracted with the crude extraction but gave 5 out of 9 positive amplification in the first leaf and 1 out of 9 in the second leaf with the commercial DNA extraction (from $1.7 \times 10^{3}$ to $3.8 \times 10^{3}$ cells $/ \mu \mathrm{L}$ and $2.9 \times 10^{2}$ cells $/ \mu \mathrm{L}$, respectively), with $\mathrm{Tp}$ ranging from $36 \mathrm{~min} 33 \mathrm{~s}$ to $44 \mathrm{~min} 46 \mathrm{~s}$ and annealing temperature ranging from $88.43{ }^{\circ} \mathrm{C}$ to $88.92^{\circ} \mathrm{C}$. The $30 \mu \mathrm{L}$ test produced only one positive amplification with DNA obtained with the crude extraction with $\mathrm{Tp} 30 \mathrm{~min} 14 \mathrm{~s}\left(7.2 \times 10^{4}\right.$ cells). The same experiment produced 2 positive amplifications with the DNA from a commercial kit in the first leaf tested with Tp $35 \mathrm{~min}$ $32 \mathrm{~s}$ and $34 \mathrm{~min} 02 \mathrm{~s}$ corresponding to $2.9 \times 10^{3}$ and $3.8 \times 10^{3}$ cells in each $\mu \mathrm{L}$. The $40 \mu \mathrm{L}$ mycelia suspension gave more positive amplifications with the crude extraction than the other assays (1 out of 9 in the first leaf tested and 2 out of 9 in the second leaf tested, $4.3 \times 10^{4}$ and $\left.9.5 \times 10^{4}\right)$. Only one of these samples produced positive amplification with the commercial DNA extraction $\left(3.6 \times 10^{3}\right.$ cells $\left./ \mu \mathrm{L}\right)$ with Tp $34 \min 41 \mathrm{~s}$.

The lowest number of cells $/ \mu \mathrm{L}$ detected was $2.9 \times 10^{2}$ cells with the commercial DNA extraction with positive amplification (in the sample inoculated with $20 \mu \mathrm{L}$ of mycelium). In general, the LAMP produced positive amplification with DNA obtained with commercial kit in samples with different amounts of $V$. inaequalis cells ranging from $2.9 \times 10^{2}$ to $3.8 \times 10^{3}$ cells $/ \mu \mathrm{L}$, with the exception of 5 samples with $5.0 \times 10^{2}, 1 \times 10^{3}, 1.2 \times 10^{3}, 1.7 \times 10^{3}, 1.9 \times 10^{3}$ cells. The DNA obtained with an alkaline method gave a lower number of positive results, but $4.3 \times 10^{4}$ cells $/ \mathrm{mL}$ for crude extraction were positively detected.

\subsection{Time Monitoring of $V$. inaequalis}

The LAMP test (Table 4) gave positive LAMP amplification in the samples extracted with the crude method at $24 \mathrm{~h}, 48 \mathrm{~h}, 5$ days, 7 days and 9 days, but not at $3 \mathrm{~h}$ after the inoculation. The same results were obtained in both repetitions. The number of positives increased over time from $1 / 9$ or $3 / 9$ to $7 / 9$ with the crude extraction method. The Tp ranged from $30 \mathrm{~min} 26 \mathrm{~s}$ to $43 \mathrm{~min} 41 \mathrm{~s}$ and the annealing temperature from $88.30^{\circ} \mathrm{C}$ to $89.47^{\circ} \mathrm{C}$. On the other hand, the LAMP gave positive amplification at all the time points when the DNA was extracted with a commercial kit. The Tp ranged from $29 \mathrm{~min}$ $22 \mathrm{~s}$ to $36 \mathrm{~min} 28 \mathrm{~s}$ and annealing temperature from $89.02^{\circ} \mathrm{C}$ to $89.47^{\circ} \mathrm{C}$ with a minimum of 5 positive results out of 9 replicates ( $3 \mathrm{~h}$ post inoculation). The minimum number of cells detected was $3.3 \times 10^{2}$ cells, and this was detected in 9 out of 9 technical replicates using DNA extracted with the commercial extraction kit and in 7 out of 9 technical replicates that represented $7.6 \times 10^{3}$ cells on the crude extract. The repetitions of the test were consistent, and no variations were shown between both repetitions.

\subsection{Naturally Infected Samples}

The results of the naturally infected samples are listed in Table 5. Thirty-two apple leaves were used to evaluate the sensitivity and reliability of the assay with naturally infected samples. Four naturally infected asymptomatic samples did not give amplification with the qPCR designed by Prencipe et al. [33] and therefore were considered true negative samples. Both of them produced negative results with both types of DNA extraction. The other samples contained between 1 to $2.7 \times 10^{4}$ cells $/ \mu \mathrm{L}$ of the DNA obtained with a commercial kit. The limit of detection of the LAMP with the commercial DNA extraction was $1.6 \times 10^{2}$ cells ( 2 out of 3 positive results). The commercial extraction samples with a number of cells higher than $1.6 \times 10^{2}$ gave positive results, with variation in the number of positives (Table 5). 
Table 4. Sensitivity testing over time of Venturia-free apple leaves, inoculated artificially with $20 \mu \mathrm{L}$ of $V$. inaequalis suspension at different time points. The LAMP assay was carried out with both types of DNA extraction (crude extraction and commercial extraction). Approximate number of cells in the crude DNA extraction and in the final elution of the commercial DNA extraction was calculated with the qPCR assay. Average of three replicates is reported. Tp $=$ time to positive, Anneal. $=$ annealing temperature. HPI: hours post inoculation.

\begin{tabular}{|c|c|c|c|c|c|c|c|c|c|}
\hline \multirow[b]{2}{*}{ Time } & \multirow{2}{*}{ Repetition } & \multicolumn{3}{|c|}{ Crude DNA Extraction } & \multirow{2}{*}{$\begin{array}{l}\mathrm{N}^{\circ} \text { Cells/mL } \\
\text { PEG Buffer }\end{array}$} & \multicolumn{3}{|c|}{ Commercial DNA Extraction } & \multirow{2}{*}{$\mathbf{N}^{\circ}$ Cells $/ \mu \mathrm{L}$} \\
\hline & & $\begin{array}{l}\text { Number of } \\
\text { Positives }\end{array}$ & TP (min:s) & Anneal. $\left({ }^{\circ} \mathrm{C}\right)$ & & $\begin{array}{c}\text { Number of } \\
\text { Positives }\end{array}$ & TP (min:s) & Anneal. $\left({ }^{\circ} \mathrm{C}\right)$ & \\
\hline $3 \mathrm{HPI}$ & Repetition 1 & $0 / 9$ & Negative & Negative & $5.4 \times 10^{4}$ & $8-9$ & $34: 03 \pm 02: 26$ & $89.20 \pm 0.22$ & $2.4 \times 10^{3}$ \\
\hline $24 \mathrm{HPI}$ & Repetition 1 & $1 / 9$ & 43:41 & 89.07 & $5.8 \times 10^{4}$ & $8-9$ & $35: 45 \pm 03: 31$ & $89.07 \pm 0.33$ & $2.5 \times 10^{3}$ \\
\hline $48 \mathrm{HPI}$ & Repetition 1 & $3 / 9$ & $37: 05 \pm 05: 24$ & $88.88 \pm 0.34$ & $4.4 \times 10^{4}$ & 9-9 & $30: 40 \pm 02: 01$ & $89.11 \pm 0.07$ & $2.0 \times 10^{3}$ \\
\hline 5 DAYS & Repetition 1 & $7 / 9$ & $34: 50 \pm 06: 00$ & $88.30 \pm 2: 33$ & $3.7 \times 10^{4}$ & 9-9 & $30: 57 \pm 03: 36$ & $89.22 \pm 0.13$ & $1.6 \times 10^{3}$ \\
\hline 7 DAYS & Repetition 1 & $5 / 9$ & $32: 48 \pm 05: 14$ & $89.18 \pm 0.25$ & $6.7 \times 10^{4}$ & 9-9 & $33: 01 \pm 03: 38$ & $89.12 \pm 0.25$ & $2.9 \times 10^{3}$ \\
\hline 9 DAYS & Repetition 1 & $7 / 9$ & $30: 26 \pm 03: 41$ & $89.34 \pm 0.18$ & $7.6 \times 10^{3}$ & $9-9$ & $32: 33 \pm 02: 10$ & $89.02 \pm 0.15$ & $3.3 \times 10^{2}$ \\
\hline 3 HPI & Repetition 2 & $0 / 9$ & Negative & Negative & $2.5 \times 10^{4}$ & $5-9$ & $36: 28 \pm 03: 41$ & $89.16 \pm 0.17$ & $1.1 \times 10^{3}$ \\
\hline $24 \mathrm{HPI}$ & Repetition 2 & $3 / 9$ & $31: 06 \pm 03: 02$ & $89.47 \pm 0.09$ & $5.7 \times 10^{4}$ & $6-9$ & $31: 06 \pm 03: 02$ & $89.47 \pm 0.09$ & $2.5 \times 10^{3}$ \\
\hline 48 HPI & Repetition 2 & $2 / 9$ & $34: 03 \pm 06: 30$ & $89.37 \pm 0.42$ & $8.7 \times 10^{4}$ & $9-9$ & $29: 39 \pm 01: 39$ & $89.34 \pm 0.14$ & $3.8 \times 10^{3}$ \\
\hline 5 DAYS & Repetition 2 & $2 / 9$ & $35: 47 \pm 03: 35$ & $88: 99 \pm 0.10$ & $5.4 \times 10^{4}$ & 9-9 & $29: 22 \pm 02: 55$ & $89.27 \pm 0.10$ & $2.3 \times 10^{3}$ \\
\hline 7 DAYS & Repetition 2 & $3 / 9$ & $37: 17 \pm 0: 3: 12$ & $89.17 \pm 0.17$ & $4.8 \times 10^{4}$ & 9-9 & $31: 08 \pm 01: 47$ & $89.10 \pm 0.13$ & $2.1 \times 10^{3}$ \\
\hline 9 DAYS & Repetition 2 & $7 / 9$ & $35: 50 \pm 03: 24$ & $89.21 \pm 0.06$ & $2.0 \times 10^{4}$ & 9-9 & $32: 56 \pm 02: 02$ & $89.07 \pm 0.19$ & $8.7 \times 10^{2}$ \\
\hline
\end{tabular}


Table 5. Comparison between the crude extraction and commercial DNA extraction using asymptomatic apple leaf samples for both types of DNA extraction (crude extraction and commercial extraction). Approximate number of cells in the crude DNA extraction and in the final elution of the commercial DNA extraction was calculated in three biological replicates with the qPCR assay. The number of positives with each extraction are also reported Tp $=$ time to positive, Anneal. $=$ annealing temperature.

\begin{tabular}{|c|c|c|c|c|c|c|c|c|}
\hline \multirow{2}{*}{ Samples } & \multicolumn{3}{|c|}{ Crude DNA Extraction } & \multirow{2}{*}{$\begin{array}{c}\text { Approximate } \\
\text { Number of Cells in } \\
1 \mathrm{~mL} \text { of PEG Buffer }\end{array}$} & \multicolumn{3}{|c|}{ Commercial DNA Extraction } & \multirow{2}{*}{$\begin{array}{l}\text { Number of Cells in } \\
1 \mu \mathrm{L} \text { of Commercia } \\
\text { DNA Extraction }\end{array}$} \\
\hline & $\begin{array}{l}\text { Number of } \\
\text { Positives }\end{array}$ & TP (min:s) & Anneal. $\left({ }^{\circ} \mathrm{C}\right)$ & & $\begin{array}{c}\text { Number of } \\
\text { Positives }\end{array}$ & TP (min:s) & Anneal. $\left({ }^{\circ} \mathrm{C}\right)$ & \\
\hline Leaf 1 & $0 / 3$ & Negative & Negative & 0 & $0 / 3$ & Negative & Negative & 0 \\
\hline Leaf 2 & $0 / 3$ & Negative & Negative & 0 & $0 / 3$ & Negative & Negative & 0 \\
\hline Leaf 3 & $0 / 3$ & Negative & Negative & 0 & $0 / 3$ & Negative & Negative & 0 \\
\hline Leaf 4 & $0 / 3$ & Negative & Negative & 0 & $0 / 3$ & Negative & Negative & 0 \\
\hline Leaf 5 & $0 / 3$ & Negative & Negative & 30 & $0 / 3$ & Negative & Negative & 1 \\
\hline Leaf 6 & $0 / 3$ & Negative & Negative & 37 & $0 / 3$ & Negative & Negative & 2 \\
\hline Leaf 7 & $0 / 3$ & Negative & Negative & 80 & $0 / 3$ & Negative & Negative & 3 \\
\hline Leaf 8 & $0 / 3$ & Negative & Negative & 95 & $0 / 3$ & Negative & Negative & 4 \\
\hline Leaf 9 & $0 / 3$ & Negative & Negative & $1.6 \times 10^{2}$ & $0 / 3$ & Negative & Negative & 7 \\
\hline Leaf 10 & $0 / 3$ & Negative & Negative & $2.1 \times 10^{2}$ & $0 / 3$ & Negative & Negative & 9 \\
\hline Leaf 11 & $0 / 3$ & Negative & Negative & $2.7 \times 10^{2}$ & $0 / 3$ & Negative & Negative & 12 \\
\hline Leaf 12 & $0 / 3$ & Negative & Negative & $6.2 \times 210^{2}$ & $0 / 3$ & Negative & Negative & 27 \\
\hline Leaf 13 & $0 / 3$ & Negative & Negative & $2.3 \times 10^{3}$ & $0 / 3$ & Negative & Negative & 92 \\
\hline Leaf 14 & $1 / 3$ & 29:14 & 89.35 & $3.4 \times 10^{5}$ & $0 / 3$ & Negative & Negative & $1.5 \times 10^{2}$ \\
\hline Leaf 15 & $1 / 3$ & $29: 47$ & 89.36 & $3.6 \times 10^{5}$ & $2 / 3$ & $35: 16 \pm 00: 09$ & $88.92 \pm 0.01$ & $1.6 \times 10^{2}$ \\
\hline Leaf 16 & $1 / 3$ & $28: 32$ & 89.52 & $4.4 \times 10^{5}$ & $2 / 3$ & $36: 10 \pm 02: 30$ & $88.99 \pm 0.10$ & $1.9 \times 10^{2}$ \\
\hline Leaf 17 & $0 / 3$ & Negative & Negative & $4.9 \times 10^{5}$ & $2 / 3$ & $35: 26 \pm 06: 41$ & $88.76 \pm 021$ & $2.1 \times 10^{2}$ \\
\hline Leaf 18 & $0 / 3$ & Negative & Negative & $6.7 \times 10^{5}$ & $2 / 3$ & $31: 51 \pm 09: 19$ & $89.14 \pm 0.32$ & $3.0 \times 10^{2}$ \\
\hline Leaf 19 & $0 / 3$ & Negative & Negative & $1.0 \times 10^{5}$ & $3 / 3$ & $33: 41 \pm 01: 50$ & $89.01 \pm 0.09$ & $3.3 \times 10^{2}$ \\
\hline Leaf 20 & $0 / 3$ & Negative & Negative & $8.2 \times 10^{5}$ & $1 / 3$ & $40: 25$ & 88.92 & $3.6 \times 10^{2}$ \\
\hline Leaf 21 & $3 / 3$ & $32: 29 \pm 08: 08$ & $89.29 \pm 0.31$ & $1.0 \times 10^{4}$ & $1 / 3$ & 38:02 & 88.62 & $4.4 \times 10^{2}$ \\
\hline Leaf 22 & $2 / 3$ & $32: 57 \pm 03: 27$ & $89.66 \pm 0.21$ & $1.0 \times 10^{4}$ & $3 / 3$ & $42: 02 \pm 00: 45$ & $88.33 \pm 0.25$ & $4.6 \times 10^{2}$ \\
\hline Leaf 23 & $1 / 3$ & $42: 40$ & 88.92 & $1.1 \times 10^{4}$ & $1 / 3$ & $27: 31$ & 89.37 & $4.9 \times 10^{2}$ \\
\hline Leaf 24 & $2 / 3$ & $36: 11 \pm 06: 00$ & $89.14 \pm 0.31$ & $1.5 \times 10^{4}$ & $3 / 3$ & $37: 02 \pm 03: 12$ & $89.07 \pm 0.21$ & $6.6 \times 10^{2}$ \\
\hline Leaf 25 & $0 / 3$ & Negative & Negative & $2.5 \times 10^{4}$ & $2 / 3$ & $36: 19 \pm 02: 05$ & $89.12 \pm 0.31$ & $1.1 \times 10^{3}$ \\
\hline Leaf 26 & $0 / 3$ & Negative & Negative & $3.1 \times 10^{4}$ & $2 / 3$ & $37: 49 \pm 03: 21$ & $89.07 \pm 0.20$ & $1.4 \times 10^{3}$ \\
\hline Leaf 27 & $1 / 3$ & $40: 40$ & 89.51 & $7.8 \times 10^{4}$ & $3 / 3$ & $36: 46 \pm 05: 33$ & $89.22 \pm 017$ & $3.4 \times 10^{3}$ \\
\hline Leaf 28 & $2 / 3$ & $34: 13 \pm 00: 01$ & $89.29 \pm 0.10$ & $1.0 \times 10^{5}$ & $3 / 3$ & $29: 49 \pm 00: 53$ & $89.06 \pm 0.15$ & $4.5 \times 10^{3}$ \\
\hline Leaf 29 & $1 / 3$ & $36: 00$ & 89.51 & $1.4 \times 10^{5}$ & $2 / 3$ & $36: 30 \pm 02: 59$ & $89.37 \pm 0.11$ & $6.0 \times 10^{3}$ \\
\hline Leaf 30 & $1 / 3$ & 36.21603 & 89.37 & $1.4 \times 10^{5}$ & $3 / 3$ & $32: 19 \pm 02: 09$ & $89.29 \pm 0.09$ & $6.1 \times 10^{3}$ \\
\hline Leaf 31 & $1 / 3$ & $30: 10$ & 89.67 & $1.5 \times 10^{5}$ & $3 / 3$ & $28: 13 \pm 01: 25$ & $89.36 \pm 0.01$ & $6.7 \times 10^{3}$ \\
\hline Leaf 32 & $1 / 3$ & $30: 58$ & 89.66 & $6.2 \times 10^{5}$ & $3 / 3$ & $32: 08 \pm 01: 04$ & $89.38 \pm 0.09$ & $2.7 \times 10^{4}$ \\
\hline
\end{tabular}


The limit of detection of the LAMP performed with the crude extracts was $3.4 \times 10^{3}$ cells. However, some of the highest concentrated samples did not give a positive result with this type of extraction.

To compare the reliability of both types of extraction, the diagnostic characteristics were compared taking into account the true positives, false positives, true negatives and false negatives of the naturally infected samples (Table 5). The specificity of the LAMP using the commercial DNA extracts surpassed the same analysis with crude-DNA extracts ( 0.43 in contrast to 0.19 of the crude extracts), while the specificity was 1.00 for both extractions. The +LR was higher than 1 in both cases and reported that 1 out of 1 positives test was really a $V$. inaequalis infected leaf. The -LR was 0.81 for the LAMP combined with crude extraction, meaning that approximately 1 in 5.9 negative amplification results were $V$. inaequalis-free apple leaves, and 0.57 for the LAMP using the commercial DNA extracts, for which the rate was 1 in 4.4, meaning than 1 out of 4.4 negative LAMP results were $V$. inaequalis-free apple leaves.

\section{Discussion}

Management of apple scab is currently based on prevention practice to reduce the inoculum spread, monitoring of orchards and nurseries and phytosanitary treatments to contrast the lifecycle stages of $V$. inaequalis [12]. Fungicide programmes against apple scab are characterized by a high number of applications during spring and summer [14]. Decision support systems were based previously on the Mills tables, but new sophisticated and more accurate predictive models such as RIMpro and A-scab are currently used to monitor $V$. inaequalis spore maturation, dissemination and infections [21,24]. Therefore, despite the great improvements in disease management to increase the yield of apple production, the current priority is focused in boosting prevention strategies [50] to reduce agrochemical use and to develop new diagnostic tools to real-time monitor $V$. inaequalis inoculum.

The LAMP assay presented in this study was validated according to the published international standard EPPO (PM7/98) and as a pest diagnosis tool through a validation including artificially infected apple leaves and naturally infected apple leaves. Inter-species phylogenetic inference has been evaluated using the ITS rDNA region by several authors, demonstrating the presence of subspecies within the monophyletic clade [50,51]; however, additional analysis using protein-coding genes such as elongation factor 1 alpha (EF-1 $\alpha$ ) or glyceraldehyde-3-phosphate dehydrogenase (G3DP) resolved the differences between the species of Venturia [50,52]. EF- $1 \alpha$ region was previously chosen by Prencipe et al. [53] to design the qPCR primers used in this study to validate the LAMP assay and consequently this gene. Due to its ability to resolve the phylogenetic relationships of closed related species, it was also selected for the design of the LAMP primers [52].

To avoid any possible non-specific amplification, other Venturia spp. were included in the analysis, such as V. pirina, V. nashicola, V. carpophila and V. cerasi, which infect different fruit tree such as European pear (Pyrus communis), Asian pear (Pyrus pyrifolia var. culta and Pyrus ussuriensis), peach (Prunus domestica) and cherry (Prunus dulcis), respectively.

It has been suggested the existence of formae speciales, or at least great population diversity within Venturia spp., based on internal transcribed spacer (ITS) polymorphisms and simple sequence repeat (SSR) markers [50,52]. Xu et al. [18] and Mansoor et al. [54] confirmed the great intra-specific variability among the pathogen population within the same orchard. Therefore, to avoid possible amplification caused by intra-species variation, the DNA of $V$. inaequalis from different apple varieties was used to develop the LAMP assay. Positive amplification was obtained only for the targets with Tp ranging from 20 to $32 \mathrm{~min}$. Testing the sensitivity of the assay is also a critical and essential point for forecasting tools. Thus, the LAMP assay was used not only with DNA samples, but also with young 'Golden Delicious' apple leaves to test the reliability of the assay. 'Golden Delicious' cultivar is one of the most commercially successful cultivars being one of the most popular choices of newly planted apple trees (https://ec.europa.eu/eurostat/statistics-explained/index.php?title=File: New_plantations_of_apple_trees_between_2012_and_2017,_by_NUTS1_regions.png) and has been reported as moderately susceptible to apple scab. These characteristics make it a suitable variety to 
test the sensitivity of the LAMP assay [8]. Fruit and young leaves are the most susceptible apple parts to $V$. inaequalis, during the growing season. It has been widely confirmed the differences of susceptibility to apple scab are a function of the age of the leaf, the mature tissues being more resistant against $V$. inaequalis $[5,20]$. Therefore, young leaves were selected to perform the 'in vivo' testing. The tests performed showed a level of sensitivity of some pg of DNA comparable with other LAMP assays previously developed $[36,38,40,45,47,55,56]$. On the other hand, the limit of detection using infected leaf samples varied in the function of the DNA extraction. One replicate of a leaf plug with $29 \times 10^{2}$ cells was detected with the commercial DNA extraction (limit of detection); however, crude extraction is the most suitable DNA extraction approach to use for LAMP assay directly in orchard. Despite the PCR-based method usually being susceptible to natural inhibitors present in the samples, affecting the detection level of the technique and even causing false negatives results [57,58], the results of the time course showed no LAMP inhibition even after the development of $V$. inaequalis on the inoculated leaves causing necrosis of the tissues. The high concentration of inhibitors and fluorescent compounds, such as chlorophylls, in the crude extraction makes necessary a 1:10 dilution before its use, facilitating amplification, however reducing its sensitivity $[57,58]$. Therefore, this type of extraction showed a higher detection limit (approximate $4.3 \times 10^{4}$ cells $/ \mathrm{mL}$ ) than the commercial DNA extraction in the artificially inoculated leaves. It is necessary to highlight that this type of experiment resembles the application of the test after rainfall that can move $V$. inaequalis ascospores. Taking into account that $4.3 \times 10^{3}$ ascospores/h per cubic metric air can be discharged during daytime hours [1] and that the ascospores can reach up to $45 \mathrm{~m}$ from the inoculum source [17], the LAMP assay was reliable in terms of sensitivity even with crude extraction. In addition, a lower number of cells was detected using crude extraction (approximate $7.6 \times 10^{3}$ cells $/ \mathrm{mL}$ ) at 9 days post inoculation.

Regarding the naturally infected apple leaves, it was considered that intensive rainfall occurred during the end of April and May 2018 (average temperature of $14.9{ }^{\circ} \mathrm{C}$ and $17.4{ }^{\circ} \mathrm{C}, 67.7 \%$ and $77.3 \%$ of relative humidity and 10 and 17 raining day in April and May, respectively; https://www.ilmeteo. it/portale/archivio-meteo/Cuneo/2018/Aprile, https://www.ilmeteo.it/portale/archivio-meteo/Cuneo/ 2018/Maggio). Previous apple scab monitoring studies were performed in Piedmont, confirming the occurrence of the first symptoms of apple scab at the beginning of June; however, the climatic conditions were favorable during this year for early $V$. inaequalis development, causing positive results in most asymptomatic samples. In terms of detected cells, even samples with at least an approximate $3.4 \times 10^{3}$ cells $/ \mathrm{mL}$ produced positive results with crude extraction. Considering that a low incidence of $V$. inaequalis is shown with an appropriate fungicide program even if the meteorological conditions are favourable for apple scab development [1] and that Wilcox et al. [59] suggested that a qualitative assessment of the primary inoculum could be sufficient to delay the first fungicide application, the sensitivity of this LAMP assay could be reliable and beneficial for in-field detection of the pathogen.

In conclusion, the development of new techniques that allow a quick diagnosis of apple scab in the field are needed to prevent disease outbreaks. The highly repetitive positive results obtained with the commercial DNA extraction make this LAMP a specific assay for laboratory-based diagnosis of apple scab. The technique presented in this study open the door to a new type of molecular diagnosis that allows the identification of $V$. inaequalis in less than an hour. Furthermore, the major advantage of the LAMP assay is its use in field in conjunction with weather monitoring systems based on new predictive models. The LAMP may be a useful tool for early diagnosis that can help after intensive rainfall to detect $V$. inaequalis in real time to develop a well-defined schedule of fungicide application without the requirement of centralized laboratories.

Supplementary Materials: The following are available online at http://www.mdpi.com/2073-4395/10/4/581/s1, Table S1: Venturia spp. sequences of the EF-1 $\alpha$ used in the multiple sequence alignment to design the LAMP primers.

Author Contributions: Conceptualization, D.S., S.F.O. and S.P.; methodology: S.F.O.; validation S.F.O. and S.P.; formal analysis, S.F.O. and S.P.; data curation, S.F.O.; writing-original draft preparation, S.F.O.; writing-review and editing, S.P., D.S. and M.L.G.; supervision: D.S. and M.L.G.; funding acquisition: D.S and M.L.G. All authors have read and agreed to the published version of the manuscript. 
Funding: The current research has received funding from the European Union Horizon 2020 program under grant agreement No 634179 "Effective Management of Pests and Harmful Alien Species-Integrated Solutions" (EMPHASIS) and the EITFood programme "CLEANFRUIT" — Standardization of innovative pest control strategies to produce zero residue fruit for baby food and other fruit produce" and from Fondazione Cassa di Risparmio di Cuneo through the project "SMART APPLE-Innovative and SMART technologies for sustainable APPLE production".

Acknowledgments: The authors gratefully acknowledge Matteo Bontà, Luca Nari and Graziano Vittone from AGRION for providing the samples.

Conflicts of Interest: The authors declare no conflicts of interest.

\section{References}

1. MacHardy, W.E. Apple Scab: Biology, Epidemiology, and Management, 2nd ed.; American Phytopathological Society: St. Paul, MN, USA, 1996; p. 545.

2. Beck, A.; Ritschel, A.; Schubert, K.; Braun, U.; Triebel, D. Phylogenetic relationships of the anamorphic genus Fusicladium s. lat. as inferred by ITS nrDNA data. Mycol. Prog. 2005, 4, 111-116. [CrossRef]

3. Bowen, J.K.; Mesarich, C.H.; Bus, V.G.M.; Beresford, R.M.; Plummer, K.M.; Templeton, M.D. Venturia inaequalis: The causal agent of apple scab. Mol. Plant Pathol. 2011, 12, 105-122. [CrossRef] [PubMed]

4. Padder, B.A.; Sofi, T.A.; Ahmad, M.; Shah, M.U.D.; Hamid, A.; Saleem, S.; Ahanger, F.A. Virulence and Molecular Diversity of Venturia inaequalis in Commercial Apple Growing Regions in Kashmir. J. Phytopathol. 2013, 161, 271-279. [CrossRef]

5. Chatzidimopoulos, M.; Ganopoulos, I.; Moraitou-Daponta, E.; Lioliopoulou, F.; Ntantali, O.; Panagiotaki, P.; Vellios, E.K. High-Resolution Melting (HRM) Analysis Reveals Genotypic Differentiation of Venturia inaequalis Populations in Greece. Front. Ecol. Evol. 2019, 7, 489. [CrossRef]

6. Gessler, C.; Patocchi, A.; Sansavini, S.; Tartarini, S.; Gianfranceschi, L. Venturia inaequalis Resistance in Apple. CRC Crit. Rev. Plant Sci. 2006, 25, 473-503. [CrossRef]

7. Holb, I.J. Classification of apple cultivar reactions to scab in integrated and organic production systems. Can. J. Plant Pathol. 2007, 29, 251-260. [CrossRef]

8. Dewdney, M.; Charest, J.; Paulitz, T.; Carisse, O. Multivariate analysis of apple cultivar susceptibility to Venturia inaequalis under greenhouse conditions. Can. J. Plant Pathol. 2003, 25, 387-400. [CrossRef]

9. MacHardy, W.E.; Gadoury, D.M.; Gessler, C. Parasitic and Biological Fitness of Venturia inaequalis: Relationship to Disease Management Strategies. Plant Dis. 2001, 85, 1036-1051. [CrossRef]

10. Köhl, J.; Scheer, C.; Holb, I.J.; Masny, S.; Molhoek, W. Toward an Integrated Use of Biological Control by Cladosporium cladosporioides H39 in Apple Scab (Venturia inaequalis) Management. Plant Dis. 2015, 99, 535-543. [CrossRef]

11. Burchill, R.T.; Hutton, K.E.; Crosse, J.E.; Garrett, C.M.E. Inhibition of the perfect stage of Venturia inaequalis (Cooke) Wint., by urea. Nature 1965, 205, 520-521. [CrossRef]

12. Michalecka, M.; Masny, S.; Leroy, T.; Puławska, J. Population structure of Venturia inaequalis, a causal agent of apple scab, in response to heterogeneous apple tree cultivation. BMC Evol. Biol. 2018, 18, 5. [CrossRef] [PubMed]

13. Köeller, W. Chemical control of apple scab—status quo and future. Norweg. J. Agric. Sci. Suppl. 1994, 17, 149-170.

14. Holb, I.J. Effect of six sanitation treatments on leaf litter density, ascospore production of Venturia inaequalis and scab incidence in integrated and organic apple orchards. Eur. J. Plant Pathol. 2006, 115, 293-307. [CrossRef]

15. Porsche, F.M.; Molitor, D.; Beyer, M.; Charton, S.; Andre, C.; Kollar, A. Antifungal Activity of Saponins from the Fruit Pericarp of Sapindus mukorossi against Venturia inaequalis and Botrytis cinerea. Plant Dis. 2018, 102, 991-1000. [CrossRef]

16. Beckerman, J.; Abbott, C. Comparative Studies on the Effect of Adjuvants with Urea to Reduce the Overwintering Inoculum of Venturia inaequalis. Plant Dis. 2019, 103, 531-537. [CrossRef]

17. Holb, I.J.; Heijne, B.; Withagen, J.C.M.; Jeger, M.J. Dispersal of Venturia inaequalis ascospores and disease gradients from a defined inoculum source. J. Phytopathol. 2004, 152, 639-646. [CrossRef]

18. Xu, X.; Harvey, N.; Roberts, A.; Barbara, D. Population variation of apple scab (Venturia inaequalis) within mixed orchards in the UK. Eur. J. Plant Pathol. 2013, 135, 97-104. [CrossRef]

19. Stensvand, A.; Eikemo, H.; Gadoury, D.M.; Seem, R.C. Use of a Rainfall Frequency Threshold to Adjust a Degree-Day Model of Ascospore Maturity of Venturia inaequalis. Plant Dis. 2005, 89, 198-202. [CrossRef] 
20. Schwabe, W.F.S. Changes in scab susceptibility of apple leaves as influenced by age. Phytophylactica 1979, 11, $53-56$.

21. Mills, W.D.; LaPlante, A.A. Apple scab. In Disease and Insects in the Orchard, 1st ed.; Mills, W.D., LaPlante, A.A., Eds.; New York College of Agriculture: New York, NY, USA, 1954; Volume 1, pp. 20-28.

22. Xu, X.M.; Butt, D.J.; Van Santen, G. A dynamic model simulating infection of apple leaves by Venturia inaequalis. Plant Pathol. 1995, 44, 865-876. [CrossRef]

23. Rossi, V.; Giosuè, S.; Bugiani, R. A-scab (Apple-scab), a simulation model for estimating risk of Venturia inaequalis primary infections. EPPO Bull. 2007, 37, 300-308. [CrossRef]

24. Philion, V.; Joubert, V.; Trapman, M.; Hjerlkrem, A.G.R.; Stensvand, A. Distribution of the Infection Time of Ascospores of Venturia inaequalis. Plant Dis. 2019, 104, 465-473. [CrossRef] [PubMed]

25. Gadoury, D.M.; Seem, R.C.; MacHardy, W.E.; Wilcox, W.F.; Rosenberger, D.A.; Stensvand, A. A Comparison of Methods Used to Estimate the Maturity and Release of Ascospores of Venturia inaequalis. Plant Dis. 2004, 88, 869-874. [CrossRef] [PubMed]

26. Giosuè, S.; Rossi, V.; Ponti, I.; Bugiani, R. Estimating the dynamics of airborne ascospores of Venturia inaequalis. EPPO Bull. 2000, 30, 137-142. [CrossRef]

27. Rossi, V.; Ponti, I.; Marinelli, M.; Giosuè, S.; Bugiani, R. Environmental factors influencing the dispersal of Venturia inaequalis ascospores in the orchard air. J. Phytopathol. 2001, 149, 11-19. [CrossRef]

28. Meitz-Hopkins, J.C.; von Diest, S.G.; Koopman, T.A.; Bahramisharif, A.; Lennox, C.L. A method to monitor airborne Venturia inaequalis ascospores using volumetric spore traps and quantitative PCR. Eur. J. Plant Pathol. 2014, 140, 527-541. [CrossRef]

29. Torfs, S.; Van Poucke, K.; Van Campenhout, J.; Ceustermans, A.; Croes, S.; Bylemans, D.; Van Hemelrijck, W.; Keulemans, W.; Heungens, K. Venturia inaequalis trapped: Molecular quantification of airborne inoculum using volumetric and rotating arm samplers. Eur. J. Plant Pathol. 2019, 155, 1319-1332. [CrossRef]

30. Daniëls, B.; De Landtsheer, A.; Dreesen, R.; Davey, M.W.; Keulemans, J. Real-time PCR as a promising tool to monitor growth of Venturia spp. in scab-susceptible and -resistant apple leaves. Eur. J. Plant Pathol. 2012, 134, 821-833. [CrossRef]

31. Schnabel, G.; Jones, A.L. The $14 \alpha$ - Demethylase (cyp51A1) Gene is Overexpressed in Venturia inaequalis Strains Resistant to Myclobutanil. Phytopathology 2000, 91, 102-110. [CrossRef]

32. Stehmann, C.; Pennycook, S.; Plummer, K.M. Molecular identification of a sexual interloper: The pear pathogen, Venturia pirina, has sex on apple. Phytopathology 2001, 91, 633-641. [CrossRef]

33. Prencipe, S.; Sillo, F.; Garibaldi, A.; Gullino, M.L.; Spadaro, D. Development and validation of a highly sensitive real-time PCR TaqMan ${ }^{\circledR}$ assay for specific detection and quantification of Venturia inaequalis in apple leaves and fruit and in air samples. Plant Dis. 2020. accepted.

34. Notomi, T.; Okayama, H.; Masubuchi, H.; Yonekawa, T.; Watanabe, K.; Amino, N.; Hase, T. Loop-mediated isothermal amplification of DNA. Nucleic Acids Res. 2000, 28, E63. [CrossRef] [PubMed]

35. Nagamine, K.; Hase, T.; Notomi, T. Accelerated reaction by loop-mediated isothermal amplification using loop primers. Mol. Cell. Probes 2002, 16, 223-229. [CrossRef] [PubMed]

36. Tomlinson, J.A.; Dickinson, M.J.; Boonham, N. Rapid Detection of Phytophthora ramorum and P. kernoviae by Two-Minute DNA Extraction Followed by Isothermal Amplification and Amplicon Detection by Generic Lateral Flow Device. Phytopathology 2010, 100, 143-149. [CrossRef] [PubMed]

37. Bekele, B.; Hodgetts, J.; Tomlinson, J.; Boonham, N.; Nikoli, P.; Swarbrick, P.; Dickinson, M. Use of a real-time LAMP isothermal assay for detecting 16SrII and XII phytoplasmas in fruit and weeds of the Ethiopian Rift Valley. Plant Pathol. 2011, 60, 345-355. [CrossRef]

38. Tomlinson, J.A.; Ostoja-Starzewska, S.; Adams, I.P.; Miano, D.W.; Abidrabo, P.; Kinyua, Z.; Alicai, T.; Dickinson, M.J.; Peters, D.; Boonham, N.; et al. Loop-mediated isothermal amplification for rapid detection of the causal agents of cassava brown streak disease. J. Virol. Methods 2013, 191, 148-154. [CrossRef]

39. Hodgetts, J.; Hall, J.; Karamura, G.; Grant, M.; Studholme, D.J.; Boonham, N.; Karamura, E.; Smith, J.J. Rapid, specific, simple, in-field detection of Xanthomonas campestris pathovar musacearum by loop-mediated isothermal amplification. J. Appl. Microbiol. 2015, 119, 1651-1658. [CrossRef]

40. Franco Ortega, S.; Tomlinson, J.; Hodgetts, J.; Spadaro, D.; Gullino, M.L.; Boonham, N. Development of Loop-Mediated Isothermal Amplification Assays for the Detection of Seedborne Fungal Pathogens Fusarium fujikuroi and Magnaporthe oryzae in Rice Seed. Plant Dis. 2018, 102, 1549-1558. [CrossRef] 
41. Mori, Y.; Kitao, M.; Tomita, N.; Notomi, T. Real-time turbidimetry of LAMP reaction for quantifying template DNA. J. Biochem. Biophys. Methods 2004, 59, 145-157. [CrossRef]

42. Goto, M.; Honda, E.; Ogura, A.; Nomoto, A.; Hanaki, K.I. Colorimetric detection of loop-mediated isothermal amplification reaction by using hydroxy naphthol blue. Biotechniques 2009, 46, 167-172. [CrossRef]

43. Li, W.; Lee, S.Y.; Back, C.G.; Ten, L.N.; Jung, H.Y. Loop-Mediated Isothermal Amplification for the Detection of Xanthomonas arboricola pv. pruni in Peaches. Plant Pathol. J. 2019, 35, 635-643. [PubMed]

44. White, T.J.; Bruns, T.; Lee, S.; Taylor, J. Amplification and direct sequencing of fungal ribosomal RNA genes for phylogenetics. In PCR-Protocols and Applications-A Laboratory Manual, 1st ed.; Innis, M.A., Gelfand, D.H., Sninsky, J.J., White, T.J., Eds.; Academic Press: New York, NY, USA, 1990; Volume 1, pp. 315-322.

45. O'Donnell, K.O.; Cigelnik, E.; Nirenberg, H.I. Molecular Systematics and phylogeography of the Gibberella fujikuroi Species Complex. Mycologia 1998, 90, 465-493. [CrossRef]

46. Franco Ortega, S.; Tomlinson, J.; Gilardi, G.; Spadaro, D.; Gullino, M.L.; Garibaldi, A. Rapid detection of Fusarium oxysporum f.sp. lactucae on soil, lettuce seeds and plants using loop-mediated isothermal amplification. Plant Pathol. 2018, 67, 1462-1473. [CrossRef]

47. Franco Ortega, S.; Bustos Lopez, M.P.; Nari, L.; Boonham, N.; Gullino, M.L.; Spadaro, D. Rapid detection of Monilinia fructicola and Monilinia laxa on peaches and nectarines using loop-mediated isothermal amplification. Plant Dis. 2019, 103, 2305-2314. [CrossRef] [PubMed]

48. Kibbe, W.A. OligoCalc: An online oligonucleotide properties calculator. Nucleic Acids Res. 2007, 35, W43-W46. [CrossRef] [PubMed]

49. Deng, C.H.; Plummer, K.M.; Jones, D.A.B.; Mesarich, C.H.; Shiller, J.; Taranto, A.P.; Robinson, A.J.; Kastner, P.; Hall, N.E.; Templeton, M.D.; et al. Comparative analysis of the predicted secretomes of Rosaceae scab pathogens Venturia inaequalis and $V$. pirina reveals expanded effector families and putative determinants of host range. BMC Genom. 2017, 18, 339. [CrossRef]

50. Schnabel, G.; Schnabel, E.L.; Jones, A.L. Characterization of Ribosomal DNA from Venturia inaequalis and Its Phylogenetic Relationship to rDNA from Other Tree-Fruit Venturia Species. Phytopathology 1999, 89, 100-108. [CrossRef]

51. Gladieux, P.; Zhang, X.G.; Róldan-Ruiz, I.; Caffier, V.; Leroy, T.; Devaux, M.; Van Glabeke, S.; Coart, E.; Le Cam, B. Evolution of the population structure of Venturia inaequalis, the apple scab fungus, associated with the domestication of its host. Mol. Ecol. 2010, 19, 658-674. [CrossRef]

52. Zhao, P.; Kakishima, M.; Uzuhashi, S.; Ishii, H. Multigene phylogenetic analysis of inter- and intraspecific relationships in Venturia nashicola and V. pirina. Eur. J. Plant Pathol. 2012, 132, 245-258. [CrossRef]

53. Gladieux, P.; Zhang, X.G.; Afoufa-Bastien, D.; Valdebenito Sanhueza, R.M.; Sbaghi, M.; Le Cam, B. On the Origin and Spread of the Scab Disease of Apple: Out of Central Asia. PLoS ONE 2008, 3, e1455. [CrossRef]

54. Mansoor, S.; Ahmed, N.; Sharma, V.; Jan, S.; Un Nabi, S.; Mir, J.I.; Mir, M.A.; Masoodi, K.Z. Elucidating genetic variability and population structure in Venturia inaequalis associated with apple scab diseaseusing SSR markers. PLOS ONE 2019, 14, e0224300. [CrossRef] [PubMed]

55. Tomlinson, J.A.; Boonham, N.; Dickinson, M. Development and evaluation of a one-hour DNA extraction and loop-mediated isothermal amplification assay for rapid detection of phytoplasmas. Plant Pathol. 2010, 59, 465-471. [CrossRef]

56. Tomlinson, J.A.; Dickinson, M.; Hobden, E.; Robinson, S.; Giltrap, P.M.; Boonham, N. A five-minute DNA extraction method for expedited detection of Phytophthora ramorum following prescreening using Phytophthora spp. lateral flow devices. J. Microbiol. Methods 2010, 81, 116-120. [CrossRef] [PubMed]

57. Wilson, I.G. Inhibition and facilitation of nucleic acid amplification. Appl. Environ. Microbiol. 1997, 63, 3741-3751. [CrossRef]

58. Bilodeau, G.J.; Koike, S.T.; Uribe, P.; Martin, F.N. Development of an assay for rapid detection and quantification of Verticillium dahliae in soil. Phytopathology 2012, 102, 331-343. [CrossRef]

59. Wilcox, W.F.; Wasson, D.I.; Kovach, J. Development and evaluation of an integrated, reduced-spray program using sterol demethylation inhibitor fungicides for control of primary apple scab. Plant Dis. 1992, 76, 669-677. [CrossRef]

(C) 2020 by the authors. Licensee MDPI, Basel, Switzerland. This article is an open access article distributed under the terms and conditions of the Creative Commons Attribution (CC BY) license (http://creativecommons.org/licenses/by/4.0/). 